\title{
Evaluation of Waste Energy Conversion Technology using Analitycal Hierarchy Process in Bantargebang Landfill, Indonesia
}

\author{
Sri R H Siregar ${ }^{1,{ }^{*}}$, Budiman R Saragih ${ }^{1}$, and Adi Surjosatyo $^{1}$ \\ ${ }^{1}$ Department of Mechanical Engineering, Universitas Indonesia, Kampus UI Depok 16426, Indonesia.
}

\begin{abstract}
In Indonesia, the waste to energy conversion technology has been installed and operate in some landfill, such as Bantargebang landfill where applied landfill gas recovery methods. Evaluate the running process is important to optimize the installed facilities and the other potential technology. This paper aims to evaluate the running process technology in Bantargebang landfill compare with the other waste to energy technology so it can be used as a reference for upgrading technology. Evaluation using Multi Criteria Decision Making techninque with observe method Analitycal Hierarcy Process adopt energy (energy content and net electrical output), environment (MSW reduction and GHG emission), and economic (initial cost and operation maintenance cost) as criterions. The results shows that the anaerobic digestion as alternative technology is the best technology with total point 2.71 , followed by inceneration pelletization at second rank with total point 2.70, and running process landfill gas recovery at third rank with total point 2.56.
\end{abstract}

\section{Introduction}

Municipal solid waste (MSW) production increasing due to population growth. Additionally, in developing country, quantity of solid waste is increasing depend on industrializing and life standars [1]. Municipal solid waste is potentially utilized as the energy source in waste-to-energy concept due to high level of caloric value. Damanhuri (2010) examined the caloric value inside municipal solid waste in some city of Indonesia and conclude the potential application of waste-toenergy [2].

The waste-to-energy conversion technologies from municipal solid waste are thermal conversion methods (incineration, pyrolysis, and gasification), biochemical conversion methods (anaerobic digestion), and landfill gas recovery methods [3]. In Indonesia, waste to energy conversion technologies could supply the energy demand and reduce waste volume. The other hand, the selection and evaluation of waste to energy technology are complex. Consideration of technology, economic, and environmental impact are a part of criteria to choosing the waste to energy conversion. Multi criteria decision making (MCDM) techniques are gaining popularity in sustainable energy management [4].

In literatur, there are several studies aims to selection or evaluation the waste to energy. Nixon et al (2013) evaluate some options of municipal solid waste using value measurement models of MCDM or Hierarchical Analitycal Network Process (HANP) and SuperDecisions in India [5]. Multinovic et al (2017) combine Life Cycle Analysis and Analitycal Hierarchy
Process to assess waste management [6]. Arikan et al (2017) select the solid waste disposal using MCDM and compare TOPSIS, PROMETHEE, and FuzZy TOPSIS in Turkey [1]. Wang et al (2018) evaluate the waste to energy as the best available technology using outrangking model of MCDM or interval valued fuzzy and DEMATEL in China [7].

This research aims to evaluate the running process technology in Bantargebang landfill compare with the other waste to energy technology. The research located at Bantargebang Landfill, Bekasi City, which dedicated for municipal solid waste from Jakarta City. Sanitary landfill and waste-to-energy using landfill gas recovery methods with gas engine facility applied in Bantargebang. Evaluation of the waste-to-energy technology is important to upgrading the installed facilities and the other potential technology.

\section{Methodology}

Analitycal Hierarcy Process, developed by Thomas Saaty (1980), is a method to decomposition of a complex problem into a hierarchy. The hierarchy of problem is converted into numerical values and processed to rank each alternative on a numerical scale. Step by step of Analitycal Hierarchy Process methodology explained in following step $[8,9]$ :

\subsection{Decompose problem into hierarchy}

Corresponding author: sri.rachmawati71@ui.ac.id 
The hierarchy contains of goal at the top of hierarchy, criterions and sub-criterions at levels and sub-levels of the hierarchy, and decision alternatives at the bottom of the hierarchy. The goal explain objective purposes of decision making. The criterions and sub criterions explain something from the problem to be reviewed.

\subsection{Pire wise comparison}

Each sub criteria are compared in pairs to assess their relative preference. The pair comparison include all of sub criterions. The assess scale numbers are 1-9 based on Saaty's fundamental scale. The scale of 1 indicates equally important, 3 weak importance, 5 strong importance, 7 very strong importance, 9 absolute importance, and 2, 4, 6, 8 intermediate value between importance.

\subsection{Generation of matrix}

The result of pair wise comparison from step 2 combine into square matrix form. The horizontal and vertical matrix are sub criterions and the diagonal matrix are 1.

\subsection{Calculation of eigenvalue}

The calculation of eigenvalue from generated matrix giving relative importance number of various criterion being compared.

\subsection{Checking of consistency}

Inconsistency may be arise when many pair wise comparisons are performed. In Analytical Hierarchy Process, the inconsistency may be tolerated less than 0.1 . The inconsistency is ratio between Consistency Index (CI) with Random Index (RI). The consistency index is fungtion of eigenvalue $(\lambda)$ and number of sub criterion (n). Equation 1 show the general equation of consistency index.

$$
C I=\frac{\pi-n}{n-1}
$$

Table 1. Random index for small problems

\begin{tabular}{|c|c|c|c|c|c|c|c|c|c|}
\hline $\mathrm{n}$ & 2 & 3 & 4 & 5 & 6 & 7 & 8 & 9 & 10 \\
\hline $\mathrm{RI}$ & 0 & 0.58 & 0.9 & 1.12 & 1.24 & 1.32 & 1.41 & 1.45 & 1.51 \\
\hline
\end{tabular}

The random index for small problems $(n \leq 10)$ has been determined shown in tabel 1. When the inconsistency more than 0.1 , re-normalization and reexamined of matrix comparisons may be required.

\subsection{Rating each alternative}

The rating of each alternative is multiplied by the weight of each sub criterion and aggregated to get global ratings to each criterion. The best alternative is the highest number of global ratings.
In this research, the goal is the best waste to energy technology applied in Bantargebang landfill. The criterion and sub criterions are developed from field investigation include technical aspects and non technical aspects. The alternatives are some waste to energy technology such as landfill gas recovery, anaerobic digestion, and inceneration.

\section{Technology review}

\subsection{Landfill gas recovery}

Landfill gas recovery is widely used in the world and is a well established waste to energy conversion technology. By product of this technology is landfill gas which contains mainly of methane $\left(\mathrm{CH}_{4}\right) 45 \%-60 \%$, carbon dioxide $\left(\mathrm{CO}_{2}\right)$, and the other trace gases [10]. Landfill gas has heating value and can be convert to electrical energy.

Energy content of landfill gas obtained by lower heating value (LHV). Landfill gas has LHV range from $15-21 \mathrm{MJ} / \mathrm{m}^{3}$ [5], however methane has LHV 37.2 $\mathrm{MJ} / \mathrm{m}^{3}$ [11]. Summarised characteristic of alternative waste to energy technology has been developed and be reference for this paper.

\subsection{Anaerobic digestion}

Anaerobic digestion is biochemical conversion waste to energy that only decompose organic fraction in municipal solid waste. In Bantargebang landfill, orgnic fraction mainly more than $50 \%$ of municipal solid waste. Docomposition of waste need influence of anaerobic microbes.

Gas methane from anaerobic degestion is higher than landfill gas, until $55 \%-75 \%$ of biogas production [11]. The higher gas methane increasing the energy content for this process technology. The other characterictic shown in table 2 .

\subsection{Inceneration}

Inceneration is thermochemical waste to energy technology which municipal solid waste is burned or oxidized in furnace leading with an excess supply air. This process produce flue gases at a high temperature which will be continueously feed in water boiler where steam is raised. The steam produced turn into steam turbine to generate electricity[11]. In this process mainly $90 \%$ of municipal solid waste reduced.

Inceneration can process the original waste as conventional inceneration, or process waste pellet as pelletization inceneration. Pelletization is pre-treatment process to compact the solid waste. This pre treatment can be increase energy content and decrease operation cost. The other characterictic shown in table 2.

Output of technology review based on information from the previous literatur summarised in tabel 2[5]. 
Table 2. Summary of technology alternative

\begin{tabular}{|c|c|c|c|c|c|}
\hline \multirow{2}{*}{$\begin{array}{l}\text { Criterion } \\
\text { Sub } \\
\text { Criterion }\end{array}$} & \multirow{2}{*}{ Unit } & \multirow{2}{*}{$\begin{array}{l}\text { LFG } \\
\text { Reco } \\
\text { very } \\
\end{array}$} & \multirow{2}{*}{$\begin{array}{l}\text { Anaerobic } \\
\text { Digestion }\end{array}$} & \multicolumn{2}{|c|}{ Inceneration } \\
\hline & & & & $\begin{array}{c}\text { Conven } \\
\text { tional }\end{array}$ & $\begin{array}{c}\text { Pelletiz } \\
\text { ation }\end{array}$ \\
\hline \multicolumn{6}{|l|}{ Energy } \\
\hline $\begin{array}{l}\text { Energy } \\
\text { Content }\end{array}$ & $\mathrm{MJ} / \mathrm{m}^{3}$ & $15-21$ & $20-25$ & $3.3-4.2$ & 15 \\
\hline $\begin{array}{l}\text { Net } \\
\text { Electrical } \\
\text { Output }\end{array}$ & $\begin{array}{l}\mathrm{kWh} / \mathrm{t} \\
\mathrm{MSW}\end{array}$ & 215 & $\begin{array}{l}100-150 \\
\text { OFMSW }\end{array}$ & 167 & 244 \\
\hline \multicolumn{6}{|l|}{ Environment } \\
\hline $\begin{array}{l}\text { MSW } \\
\text { Reduction }\end{array}$ & $\%$ & $\begin{array}{l}\text { Low/ } \\
\text { Slow }\end{array}$ & $\begin{array}{c}40-75 \% \\
\text { OFMSW }\end{array}$ & 90 & 18 \\
\hline $\begin{array}{l}\text { GHG } \\
\text { Emission }\end{array}$ & $\begin{array}{l}\mathrm{CO}_{2} / \mathrm{t} \\
\mathrm{MSW} \\
\end{array}$ & 1.97 & $\begin{array}{l}1.19-1.42 \\
\text { (wet-dry) }\end{array}$ & 1.67 & NA \\
\hline \multicolumn{6}{|l|}{ Economic } \\
\hline Initial Cost & $\$ / \mathrm{kW}$ & 15000 & $\begin{array}{c}242-1212 \\
(\$ / \mathrm{tpa})\end{array}$ & $\begin{array}{l}890- \\
1780 \\
\end{array}$ & $\begin{array}{l}867- \\
1175 \\
\end{array}$ \\
\hline O\&M Cost & $\$ / \mathrm{kWh}$ & $\begin{array}{l}0.08- \\
0.15\end{array}$ & 0.05 & $\begin{array}{l}0.07- \\
0.13\end{array}$ & 0.025 \\
\hline
\end{tabular}

OFMSW = Organic fraction municipal solid waste

tpa

$=$ Tons per annum

NA

$=$ Data not available

\section{Result and discussion}

Analysis of the best waste to energy technology results hierarchy shown in figure 1. Critetion consist of energy, environment, and economic. Each criterion has two sub criterion. Energy consist of energy content of fuel and net electrical output. Environment consist of volume reduction of municipal solid waste and greenhouse gas emission. Economic consist of initial cost and operation maintenance cost.

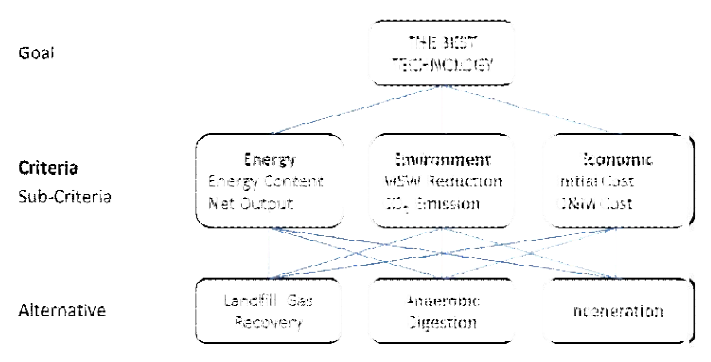

Fig 1. Hierarchy structur for evaluation

Pair wise comparison defined between each sub criterion. Based on the hierarchy, there are total 30 pairs which 15 pairs stated the strength of comparison and the other 15 pairs satisfy the reciprocal condition. To complete the matrix, the diagonal elements of matrix are 1. The pair wise comparison shown in tabel 3.

Table 3. Pair wise comparison

\begin{tabular}{|c|c|c|c|c|c|c|}
\hline & A.1 & A.2 & B.1 & B.2 & C.1 & C.2 \\
\hline A.1 & 1 & 1 & 5 & 3 & 3 & 3 \\
\hline A.2 & 1 & 1 & 3 & 3 & 3 & 3 \\
\hline
\end{tabular}

\begin{tabular}{|c|c|c|c|c|c|c|}
\hline B.1 & 0.20 & 0.33 & 1 & 1 & 1 & 3 \\
\hline B.2 & 0.33 & 0.33 & 1 & 1 & 3 & 1 \\
\hline C.1 & 0.33 & 0.33 & 1 & 0.33 & 1 & 1 \\
\hline C.2 & 0.33 & 0.33 & 0.33 & 1 & 1 & 1 \\
\hline
\end{tabular}

Where A.1 is energy - energy content, A.2 is energy - net electrical output, B1 is environment - volume reduction of municipal solid waste, B.2 is environment greenhouse gas emission, C.1 is economic - initial cost, C. 2 is economic - operation maintenance cost.

Developed pair comparison data each sub criterion is assumed based on field investigation at location of studi. Bantargebang landfill constructed with waste to energy concept which using sanitary landfill and applied landfill gas recovery technology. Energy criteria is the priority focus but not overriding environment and economic criterions.

Energy content equally important with net electrical output but more important than volume reduction of municipal solid waste and slightly more important than the others sub criterions. Net electrical output slightly more important than volume reduction of municipal solid waste, greenhouse gas emission, initial cost, and operation maintenance cost. Volume reduction of municipal solid waste equally important with greenhouse gas emission and initial cost, but slightly more important than operation maintanance cost. Greenhouse gas emission slightly more important than initial cost but equally important with operation maintenace cost. Initial cost equally important with operation maintenance cost.

This pair wise comparison has inconsistency less then 0.1 and the eigen value as a weighting of each criterion shown in tabel 4 .

Table 4. Weighting each sub criterion

\begin{tabular}{|c|c|}
\hline Sub Criterion & Weighting \\
\hline Energy Content & 0.313 \\
\hline Net Electrical Output & 0.283 \\
\hline MSW Reduction & 0.115 \\
\hline GHG Emission & 0.122 \\
\hline Initial Cost & 0.082 \\
\hline O\&M Cost & 0.085 \\
\hline
\end{tabular}

The range of sub criterion weighting is $0.082-0.313$. Energy content has the highest weighting and initial cost has the lowest weighting. The large order of weighted values are energy content, net electrical output, MSW reduction, GHG emission, O\&M cost, and initial cost. This weighting value multiplied with the rank of alternative technology to result the best technology.

The rank is organized by summary of technology alternative shown in table 2. For energy content, net electrical output, MSW reduction, and GHG emission the highest value is best technology, but for initial cost and operation maintenance cost the lowest value is the best technology. The biggest ranking number is for the best technology. Summary for sub criterion ranking shown in figure 2 . 


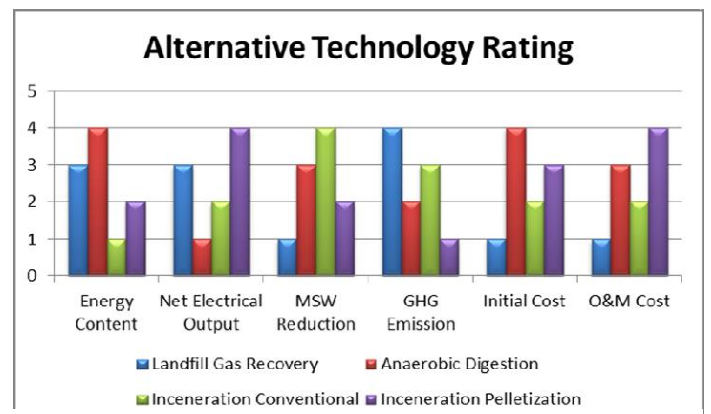

Fig 2. Sub criterion ranking

The highest value for energy content is anaerobic digestion, so anaerobic digestion has ranking number 4 . Then ranking number 3 for landfill gas recovery, ranking number 2 for inceneration pelletization, and ranking number 1 for inceneration conventional.

The highest value for net electrical output is inceneration pelletization, so inceneration pelletization has ranking number 4 . Then ranking number 3 for landfill gas recovery, ranking number 2 for inceneration conventional, and ranking number 1 for anaerobic digestion. Net electrical output for anaerobic digestion only mention for organic fraction of municipal solid waste. In Bantargebang landfill organic fraction is until $50 \%$ of total municipal solid waste, so that the anaerobic digestion is the lowest value for net electrical output point of view.

The highest value for municipal solid waste reduction is inceneration conventional, so inceneration conventional has ranking number 4 . Then ranking number 3 for anaerobic digestion, ranking number 2 for inceneration pelletization, and ranking number 1 for landfill gas recovery. Municipal solid waste reduction for anaerobic digestion only mention for organic fraction of municipal solid waste. Altough, anaerobic digestion reduct $40-75 \%$ organic fraction, that is still higher than inceneration pelletization and landfill gas recovery.

The highest value for greenhouse gas emission is landfill gas recovery, so landfill gas recovery has ranking number 4 . Then ranking number 3 for inceneration conventional, ranking number 2 for anaerobic digestion, and ranking number 1 for inceneration pelletization. There is no data for greenhouse gas emission of inceneration pelletization, so assumed that inceneration pelletization has the lowest value of greenhouse gas emission.

The lowest value for initial cost is anaerobic digestion, so anaerobic digestion has ranking number 4. Then ranking number 3 for inceneration pelletization, ranking number 2 for inceneration conventional, and ranking number 1 for landfill gas recovery.

The lowest value for initial cost is inceneration pelletization, so inceneration pelletization has ranking number 4. Then ranking number 3 for anaerobic digestion, ranking number 2 for inceneration conventional, and ranking number 1 for landfill gas recovery.
The weighting value multiplied with sub criterion ranking to result the best technology.from this hierarchy. Total multiplied each technology shown in figure 3.

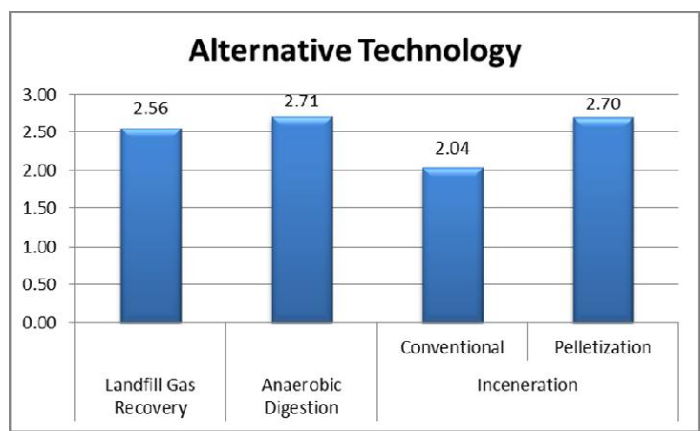

Fig 3. Alternative technology

The best technology from this hierarhcy is anaerobic digestion with total point 2.71 , followed by inceneration pelletization with total point 2.70 at the second alternative. The running technology process, landfill gas recovery ranks third alternative with total point 2.56 and the last is inceneration conventional with total point 2.04 .

\section{Conclusion}

This paper has compares four alternative technology using analitycal hierarchy process for Bantargebang landfill. The running technology of Bantargebang landfill is landfill gas recovery. However, this evaluation results the anaerobic digestion as alternative technology is the best technology to applied in this landfill, followed by inceneration with pelletization at second rank, and running process landfill gas recovery at third rank.

This paper focus in technical aspect include environment and economic. This paper provides an overview of the use of AHP methods to evaluate technology. The government can equip with social aspect to get result which integrated and can be implemented.

We would like to acknowledgement the support from Dinas Lingkungan Hidup dan Kebersihan DKI Jakarta, as operator in Bantargebang landfill.

\section{References}

1. Arıkan, E., Z.T. Şimşit-Kalender, and Ö. Vayvay, Journal of Cleaner Production, Solid waste disposal methodology selection using multi-criteria decision making methods and an application in turkey. 142: p. 403-412, (2017).

2. Damanhuri, D.M.N.d.E., Jurnal Teknik Lingkungan, Heating value based on compositon and characterictics of municipal solid waste in indonesia in waste to energy concept. Volume 16(Nomor 2): p. hal. 103-114, (2010).

3. Beyene, H.D., A.A. Werkneh, and T.G. Ambaye, Renewable Energy Focus, Current 
updates on waste to energy (wte) technologies:

A review. 24: p. 1-11, (2018).

4. Pohekar, S.D. and M. Ramachandran, Renewable and Sustainable Energy Reviews, Application of multi-criteria decision making to sustainable energy planning - a review. 8(4): p. 365-381, (2004).

5. Nixon, J.D., et al., Energy, Evaluation of options for energy recovery from municipal solid waste in india using the hierarchical analytical network process. 59: p. 215-223, (2013).

6. Milutinović, B., et al., Energy, Environmental assessment of waste management scenarios with energy recovery using life cycle assessment and multi-criteria analysis. 137: p. 917-926, (2017).

7. Wang, Z., et al., Journal of Cleaner Production, Waste-to-energy, municipal solid waste treatment, and best available technology: Comprehensive evaluation by an intervalvalued fuzzy multi-criteria decision making method. 172: p. 887-899, (2018).

8. Saaty, T.L., European journal of operational research, Decision-making with the ahp: Why is the principal eigenvector necessary. 145(1): $\mathrm{p}$. 85-91, (2003).

9. Saaty, R.W., Mathematical Modelling, The analytic hierarchy process-what it is and how it is used. 9(3): p. 161-176, (1987).

10. Themelis, N.J. and P.A. Ulloa, Renewable Energy, Methane generation in landfills. 32(7): p. 1243-1257, (2007).

11. Ogunjuyigbe, A., T. Ayodele, and M. Alao, Renewable and Sustainable Energy Reviews, Electricity generation from municipal solid waste in some selected cities of nigeria: An assessment of feasibility, potential and technologies. 80: p. 149-162, (2017). 